\title{
Regional data assimilation of multi-spectral MOPITT observations of CO over North America
}

\author{
Z. Jiang ${ }^{1,2}$, D. B. A. Jones ${ }^{1,3}$, J. Worden ${ }^{2}$, H. M. Worden ${ }^{4}$, D. K. Henze ${ }^{5}$, and Y. X. Wang ${ }^{6,7}$ \\ ${ }^{1}$ Department of Physics, University of Toronto, Toronto, ON, Canada \\ ${ }^{2}$ Jet Propulsion Laboratory, California Institute of Technology, Pasadena, CA, USA \\ ${ }^{3}$ JIFRESSE, University of California, Los Angeles, Los Angeles, CA, USA \\ ${ }^{4}$ National Center for Atmospheric Research, Boulder, CO, USA \\ ${ }^{5}$ University of Colorado, Boulder, CO, USA \\ ${ }^{6}$ Department of Marine Sciences, Texas A\&M University at Galveston, Galveston, TX, USA \\ ${ }^{7}$ Ministry of Education Key Laboratory for Earth System Modeling, Center for Earth System Science, Institute for Global \\ Change Studies, Tsinghua University, Beijing, China
}

Correspondence to: Z. Jiang (zhe.jiang@jpl.nasa.gov)

Received: 26 January 2015 - Published in Atmos. Chem. Phys. Discuss.: 25 February 2015

Revised: 06 June 2015 - Accepted: 08 June 2015 - Published: 19 June 2015

\begin{abstract}
Chemical transport models (CTMs) driven with high-resolution meteorological fields can better resolve small-scale processes, such as frontal lifting or deep convection, and thus improve the simulation and emission estimates of tropospheric trace gases. In this work, we explore the use of the GEOS-Chem four-dimensional variational (4D-Var) data assimilation system with the nested high-resolution version of the model $\left(0.5^{\circ} \times 0.67^{\circ}\right)$ to quantify North American CO emissions during the period of June 2004-May 2005. With optimized lateral boundary conditions, regional inversion analyses can reduce the sensitivity of the $\mathrm{CO}$ source estimates to errors in long-range transport and in the distributions of the hydroxyl radical $(\mathrm{OH})$, the main sink for $\mathrm{CO}$. To further limit the potential impact of discrepancies in chemical aging of air in the free troposphere, associated with errors in $\mathrm{OH}$, we use surface-level multispectral MOPITT (Measurement of Pollution in The Troposphere) CO retrievals, which have greater sensitivity to $\mathrm{CO}$ near the surface and reduced sensitivity in the free troposphere, compared to previous versions of the retrievals. We estimate that the annual total anthropogenic $\mathrm{CO}$ emission from the contiguous US 48 states was $97 \mathrm{TgCO}$, a $14 \%$ increase from the $85 \mathrm{TgCO}$ in the a priori. This increase is mainly due to enhanced emissions around the Great Lakes region and along the west coast, relative to the a priori. Sensitivity analyses using different $\mathrm{OH}$ fields and lateral boundary conditions suggest a possible er-
\end{abstract}

ror, associated with local North American $\mathrm{OH}$ distribution, in these emission estimates of $20 \%$ during summer 2004, when the CO lifetime is short. This $20 \% \mathrm{OH}$-related error is $50 \%$ smaller than the $\mathrm{OH}$-related error previously estimated for North American CO emissions using a global inversion analysis. We believe that reducing this $\mathrm{OH}$-related error further will require integrating additional observations to provide a strong constraint on the $\mathrm{CO}$ distribution across the domain. Despite these limitations, our results show the potential advantages of combining high-resolution regional inversion analyses with global analyses to better quantify regional $\mathrm{CO}$ source estimates.

\section{Introduction}

Inverse modeling is a powerful tool to improve our understanding of emissions of greenhouse gases and pollutant tracers, by combining observations of atmospheric composition with models. Despite more than a decade of inverse modeling work to better quantify emissions of atmospheric CO (e.g., Palmer et al., 2003; Pétron et al., 2004; Heald et al., 2004; Arellano Jr. et al., 2006; Jones et al., 2009; Kopacz et al., 2010; Gonzi et al., 2011; Fortems-Cheiney et al., 2012), there is significant uncertainty in regional $\mathrm{CO}$ source estimates, reflecting varying source estimates from the inverse modeling 
analyses. As noted in previous studies, the discrepancies between the estimated $\mathrm{CO}$ emissions from different inversion analyses are due, in part, to errors in the atmospheric models used in the inversions. Model errors in long-range transport, vertical convective transport, diffusion, and chemistry (e.g. Arellano Jr. et al., 2006; Fortems-Cheiney et al., 2011; Locatelli et al., 2013; Worden et al., 2013; Jiang et al., 2011, 2013, 2015) all adversely impact the inverse modeling of CO and other trace constituents (such as methane), and mitigating these errors in global models is challenging.

One way to reduce the effects of some model errors is to carry out the model simulations at high spatial resolution, which allows an improved description of small-scale processes, particularly those associated with vertical convection and diffusion. There have been several studies using high-resolution mesoscale models for inversion analyses (e.g. Stroud et al., 2011; Valin et al., 2011; Klich and Fuelberg, 2014; Stock et al., 2014) with the lateral boundary conditions provided from global, coarse resolution models (e. g. Curci et al., 2010; Peylin et al., 2011). However, the consistency of boundary conditions becomes a critical issue in these regional analyses (e.g. Göckede et al., 2010). The boundary conditions have also been imposed based on independent data, such as aircraft in situ measurements (e.g. Brioude et al., 2012; Lauvaux et al., 2012; Wecht et al., 2014).

Regional inverse modeling of $\mathrm{CO}$ emissions with adequate boundary condition optimization will also reduce the impact of discrepancies in long-range transport and in the chemical sink of CO. Reducing the sensitivity to the chemical sink of $\mathrm{CO}$ also requires that transport across the regional domain is fast compared to the lifetime of CO. Jiang et al. (2015) compared $\mathrm{CO}$ source estimates inferred from inversion analyses of surface-level and profile retrievals of $\mathrm{CO}$ from the MOPITT (Measurement of Pollution in The Troposphere) satellite instrument and found that they were generally consistent (to within 10\%), except for source estimates for North America, Europe, and East Asia. In an earlier study, Jiang et al. (2013) noted that when comparing source estimates inferred from in situ surface data and from satellite observations, "in the absence of transport bias, the surface and satellite data should provide consistent constraints on the sources, if the data coverage is representative of the spatiotemporal variability in CO". They were the first to show a large discrepancy in the Asian source estimates obtained from the MOPITT surface-level and profile retrievals, and they argued that it was due to errors in convective transport over Asia associated with the Asian summer monsoon. In addition to transport biases, discrepancies in the chemical sink of $\mathrm{CO}$ will also impact the constraints on the surface sources provided by the surface-level and free tropospheric data. Jiang et al. (2015) suggested that the differences in the North American and European sources that they estimated from the MOPITT surface-level and profile retrievals could be due to the fact that air in the free troposphere over North America and
Europe is more chemically aged; thus, the surface-level and profile data are sampling air with different $\mathrm{CO}$ characteristics, with the profile data being more susceptible to biases in the chemical sink.

The work presented here is based on the global analysis of Jiang et al. (2015), but employs the high-resolution, regional version of GEOS-Chem (e.g. Wang et al., 2004; Chen et al., 2009) and the MOPITT surface-level retrievals to better quantify North American emissions of $\mathrm{CO}$. We focus on the period June 2004 to May 2005 for consistency with Jiang et al. (2015) and Kopacz et al. (2010). As mentioned above, regional inversion analyses are sensitive to the lateral boundary conditions, but use of global models to provide these boundary conditions is problematic if there are biases in transport and the chemistry in the models. Use of in situ observations to provide boundary conditions is also problematic because observational coverage is often limited in space and time. A better approach for imposing the boundary conditions is to assimilate satellite observations that can provide a strong constraint on the distribution of $\mathrm{CO}$ throughout the free troposphere. Here we explore the use of the MOPITT data to constrain the lateral boundary conditions as well as the surface $\mathrm{CO}$ emissions. We also examine the potential impact of discrepancies in the abundance of the hydroxyl radical $(\mathrm{OH})$, the main $\mathrm{CO}$ sink, on the estimates $\mathrm{CO}$ sources in a regional inverse modeling context.

This paper is organized as follows: in Sect. 2 we describe the MOPITT instruments and the GEOS-Chem model. In Sect. 3 we outline the inversion framework used in this work. In Sect. 4, we describe our approach for initial and boundary condition optimization, and present the estimated monthly mean North American emissions. The sensitivity of the source estimates to the chemical sink is examined by comparing the inversion results obtained with two different OH fields. Our conclusions are then provided in Sect. 5.

\section{Observations and model}

\subsection{MOPITT}

The MOPITT instrument was launched on 18 December 1999, on NASA's Terra spacecraft. We employ the multispectral version 5 (V5J) retrievals, in which the thermal infrared (TIR) radiances at $4.7 \mu \mathrm{m}$ are combined with the near infrared (NIR) radiances at $2.3 \mu \mathrm{m}$ to provide greater sensitivity to lower tropospheric CO over land (Worden et al., 2010; Deeter et al., 2011). The retrievals are conducted with respect to the logarithm of the volume mixing ratio (VMR), and are reported on a 10-level pressure grid (surface, 900, $800,700,600,500,400,300,200$, and $100 \mathrm{hPa}$ ). Although we use only the surface-level MOPITT retrievals in our analysis, it is necessary to transform the modeled CO profile to account for the vertical resolution of the MOPITT retrieval. This transformation is carried out using the following obser- 
vation operator

$F(\boldsymbol{x})=\boldsymbol{y}_{\mathrm{a}}+\mathbf{A}\left(H(\boldsymbol{x})-\boldsymbol{y}_{\mathrm{a}}\right)$,

where $\mathbf{A}$ is the MOPITT averaging kernel, $H(\boldsymbol{x})$ is the GEOS-Chem profile of CO (interpolated onto the MOPITT retrieval grid), and $\boldsymbol{y}_{\mathrm{a}}$ is the MOPITT a priori profile. After transforming the modeled profile, the modeled $\mathrm{CO}$ at the surface is compared to the surface-level MOPITT CO, as described in Eq. (2) in Sect. 3. Deeter et al. (2012, 2013) evaluated the multispectral MOPITT data and reported a small positive bias of $2.7 \%$ at the surface and a larger positive bias of $14 \%$ at $200 \mathrm{hPa}$ for the $\mathrm{V} 5 \mathrm{~J}$ data. The large bias in the upper troposphere is not an issue here since we focus on the surface-level data. Further details for the MOPITT instrument and the multispectral retrievals are given in Jiang et al. (2015).

\subsection{GEOS-Chem}

The GEOS-Chem global chemical transport model (CTM) (http://www.geos-chem.org) is driven by assimilated meteorological fields from the NASA Goddard Earth Observing System (GEOS-5) at the Global Modeling and data Assimilation Office. The standard GEOS-Chem chemical mechanism includes 43 tracers, and simulates a detailed description of tropospheric $\mathrm{O}_{3}-\mathrm{NO}_{x}$-hydrocarbon chemistry, including the radiative and heterogeneous effects of aerosols. The native horizontal resolution of GEOS-5 is $0.5^{\circ} \times 0.667$, but the meteorological fields are usually degraded to $4^{\circ} \times 5^{\circ}$ or $2^{\circ} \times 2.5^{\circ}$ for global-scale simulations

Our analysis is based on the CO-only simulation in GEOSChem v8-02-01, with relevant updates through v9-01-01, using archived monthly $\mathrm{OH}$ fields from the full chemistry run. The standard $\mathrm{OH}$ field used in this work is from GEOSChem version v5-07-08 (Evans et al., 2005). In order to study the influence of the $\mathrm{OH}$ distribution on the inversion analyses, we also archive the $\mathrm{OH}$ fields from a v8-02-01 GEOSChem full chemistry simulation. Additional details about $\mathrm{OH}$ fields and emission inventories can be found in Jiang et al. (2015). Briefly, the annual North American sources of CO are $134 \mathrm{Tg}$ CO from fossil fuel and biofuel combustion and biomass burning, $61 \mathrm{Tg} \mathrm{CO}$ from the oxidation of biogenic volatile organic compounds (VOCs), and $71 \mathrm{Tg} \mathrm{CO}$ from the oxidation of $\mathrm{CH}_{4}$. Figure 1 shows the distribution of the annual mean CO emissions for June 2004 to May 2005.

The inversion analyses here are carried out using the GEOS-Chem four-dimensional variational (4D-Var) data assimilation system, which was first described by Henze et al. (2007) and has been widely used in the chemical assimilation of CO and other tracer gases (e.g. Kopacz et al., 2009, 2010; Singh et al., 2011; Wells et al., 2014; Deng et al., 2014). Previous GEOS-Chem CO inversion analyses were conducted with the global version of the model. Here we extend the 4D-Var system to enable regional inverse modeling of $\mathrm{CO}$ using the nested version of GEOS-Chem.

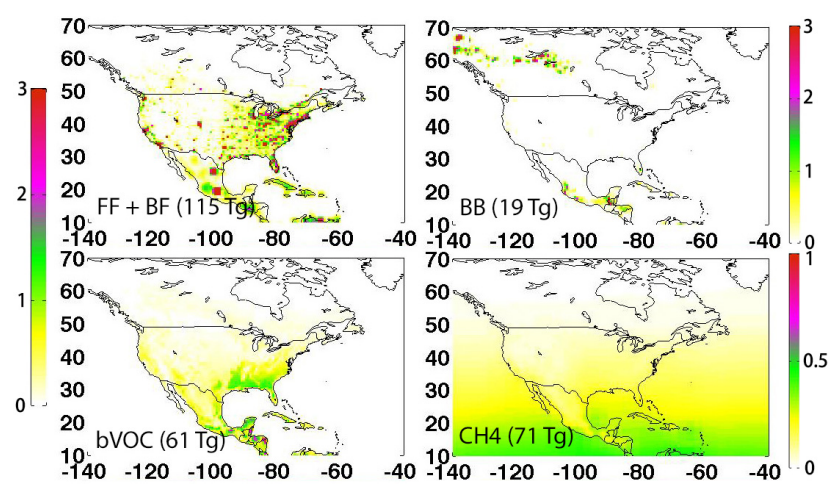

Figure 1. Annual mean $\mathrm{CO}$ emissions from fossil fuel (FF), biofuel (BF), biomass burning (BB) and the oxidation of biogenic nonmethane volatile organic compounds (NMVOC) and $\mathrm{CH}_{4}$, averaged for June 2004 to May 2005. The unit is $10^{12}$ molec $\mathrm{cm}^{-2} \mathrm{~s}^{-1}$.

The nested capability was first implemented in GEOSChem by Wang et al. (2004) for the GEOS-3 version of the meteorological fields. The model was then updated by Chen et al. (2009) to support the GEOS-5 meteorological fields, with $0.5^{\circ} \times 0.667^{\circ}$ resolution, which are used here. In the nested simulation the boundary conditions are based on fields archived from a global simulation (at $4^{\circ} \times 5^{\circ}$ or $2^{\circ} \times 2.5^{\circ}$ ) with a 3-hour temporal resolution, which are used to rewrite the tracer concentrations in a buffer zone around the nested domain before every transport step. Along the boundary of the nested domain, the direction of the wind field is used to identify whether the flow is directed into or out of the domain, and the mixing ratios of the tracers in the buffer zone are used to provide the necessary upstream information. A key benefit of using the nested model was shown by Wang et al. (2004), who found that the CO mixing ratios in the high-resolution nested simulation were lower than in the coarse resolution global model, which they attributed to the failure of the coarse global model to capture subgrid vertical motions. Figure 2 shows the simulated $\mathrm{CO}$ mixing ratio on 1 May 2006, obtained with the $4^{\circ} \times 5^{\circ}$ global simulation and with the nested North American simulation. The yellow box in Fig. 2 indicates the buffer zone in which the boundary conditions are applied. As shown in the figure, the highresolution $\mathrm{CO}$ distribution better reflects the influence of the mid-latitude cyclone present over central North America, and the urban emission centers can be more clearly identified in the high-resolution simulation.

\section{Inversion approach}

The inverse method seeks an optimal estimate of the CO sources that is consistent with both the observed atmospheric concentrations and the a priori constraints on the sources by minimizing the cost function 


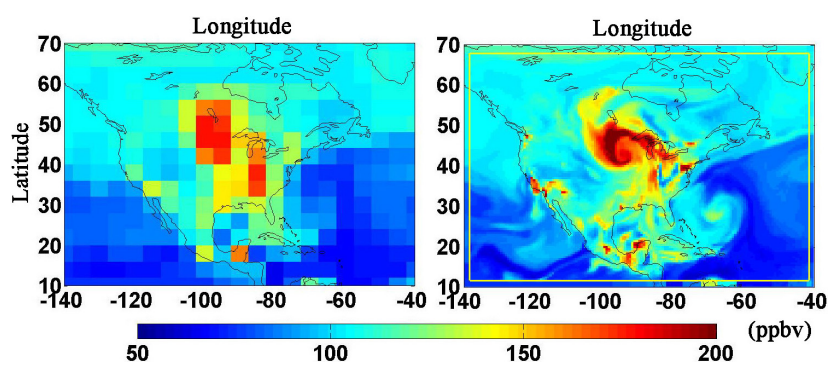

Figure 2. CO mixing ratio in GEOS-Chem on level 10 (about $850 \mathrm{hPa}$ ) on $1 \mathrm{May}, 2006$. The influence of a mid-latitude cyclone is clearly shown in the high-resolution $\left(0.5^{\circ} \times 0.667^{\circ}\right)$ simulation (right), whereas it is not obvious in that with coarse resolution $\left(4^{\circ} \times 5^{\circ}\right)$ simulation (left). The light yellow line on the $0.5^{\circ} \times 0.667^{\circ}$ plot demarcates the buffer zone in which the coarse resolution boundary conditions are imposed.

$$
\begin{aligned}
J(\boldsymbol{x}) & =\sum_{i=1}^{N}\left(F_{i}(\boldsymbol{x})-\boldsymbol{y}_{i}\right)^{T} \mathbf{S}_{\Sigma}^{-1}\left(F_{i}(\boldsymbol{x})-\boldsymbol{y}_{i}\right) \\
& +\left(\boldsymbol{x}-\boldsymbol{x}_{\mathrm{a}}\right)^{T} \mathbf{S}_{\mathrm{a}}^{-1}\left(\boldsymbol{x}-\boldsymbol{x}_{\mathrm{a}}\right),
\end{aligned}
$$

where $\boldsymbol{x}$ is the state vector of emissions, $N$ is the total number of observations assimilated over the assimilation window (which is 1 month), $\boldsymbol{y}_{i}$ is the $i$ th vector of observed concentrations (the MOPITT surface-level retrievals), and $F(\boldsymbol{x})$ is the forward model, which accounts for the vertical smoothing of the MOPITT retrieval and is described in Eq. (1). Here $\boldsymbol{x}_{\mathrm{a}}$ is the a priori estimate and $\mathbf{S}_{\Sigma}$ and $\mathbf{S}_{\mathrm{a}}$ are the observational and a priori error covariance matrices, respectively. The first term on the right in Eq. (2) represents the mismatch between the simulated and observed concentrations weighted by the observation error covariance. The second term represents the departure of the estimate from the a priori. The cost function is iteratively minimized using the L-BFGS algorithm (Liu and Nocedal, 1989). The inversion approach is exactly the same as described in Jiang et al. (2015). We, therefore, refer the reader to Jiang et al. (2015) for details of the optimizing scheme, the MOPITT data selection criteria, and the specification of the error covariance matrices. We employed an observing system simulation experiment (OSSE) to evaluate our high-resolution 4D-Var system in the Appendix, which suggested the nested inversion has similar reliability as the global scale assimilation system.

\section{Results and discussion}

\subsection{Optimization on the initial and boundary conditions}

We produce initial conditions following the approach of Jiang et al. (2015), by assimilating MOPITT V5J tropospheric profile data using the sequential sub-optimal Kalman filter (Parrington et al., 2008) from 1 January 2004 to 1 May 2005. Because of the bias in the V5J data at $200 \mathrm{hPa}$, we assimilate the profile data only below $200 \mathrm{hPa}$. The optimized CO distribution from the Kalman filter is archived at the beginning of each month, providing the initial conditions at the beginning of each month for the 4D-Var inversion analyses.

As mentioned above, the lateral boundary conditions for the nested simulation could be specified from the global model. However, a better approach would be to constrain the global-scale and regional-scale emissions within the same inversion framework, so that the optimized emissions on the global-scale will provide less biased boundary conditions for the regional inversion. Such an approach has been used to constrain $\mathrm{CH}_{4}$ and $\mathrm{N}_{2} \mathrm{O}$ emissions over South America and Europe (Meirink et al., 2008; Bergamaschi et al., 2010; Corazza et al., 2011) with the nested TM5 model. An issue with this approach is that the adjustment in the emissions on the global scale will have to be projected through long-range transport to the nested domain. If there are any biases in the model transport, those biases will also be projected onto the nested inversion.

Because the GEOS-Chem nesting is one-way, we cannot implement the same approach that is used in TM5. Instead, we conduct a global-scale inversion analysis and use the a posteriori $\mathrm{CO}$ fields as boundary conditions for the regional inversion. The a posteriori simulation from the global scale inversion should provide less biased boundary conditions for the regional scale inversion than the free running model (without assimilation). However, as mentioned above, the boundary conditions could potentially be problematic if there are biases in the model transport. Alternatively, one could optimize the model $\mathrm{CO}$ distribution (using the sequential suboptimal Kalman filter, for example), over writing any potential discrepancy in the tracer distribution associated with errors in the model transport (or chemistry). Here we compare the $\mathrm{CO}$ distribution obtained from optimizing the $\mathrm{CO}$ distribution using the Kalman filter and from optimizing the $\mathrm{CO}$ sources using the 4D-Var system.

The relative differences in the $\mathrm{CO}$ distribution obtained from these two assimilation approaches are shown in Fig. 3. The assimilation of the MOPITT tropospheric profiles with the sequential sub-optimal Kalman filter from 1 January 2004 to 1 June 2005 is referred to as CO_KF. The a posteriori $\mathrm{CO}$ distribution obtained from optimizing the monthly mean $\mathrm{CO}$ emissions using the $4 \mathrm{D}$-Var scheme is referred to as CO_EMS. Shown in Fig. 3 are the relative differences of the lower tropospheric (surface-500 hPa) partial columns, calculated as (CO_EMS - CO_KF) / CO_KF. Since both approaches used the same initial conditions, archived from the Kalman filter assimilation, at the beginning of each month, the relative differences shown in Fig. 3 can be considered to be the residual bias in the a posteriori simulation that cannot be effectively removed within the 1-month assimilation period by adjusting only the surface emissions. The most 


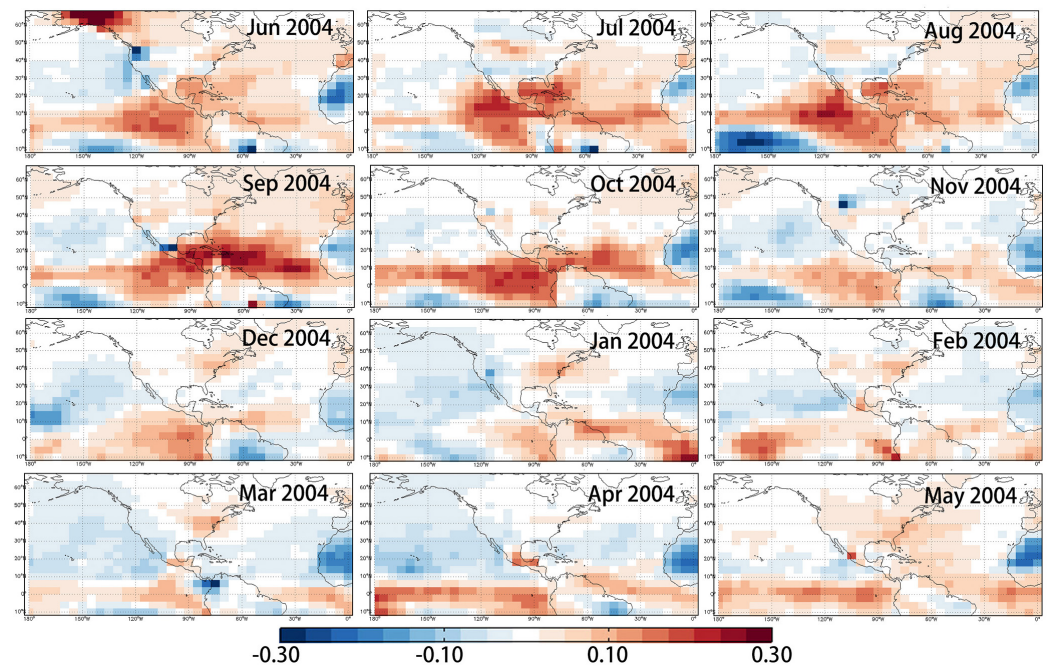

Figure 3. Relative difference between the optimized lower tropospheric partial columns (surface-500 hPa) between the Kalman filter assimilation, referred to as CO_KF and a posteriori simulation of global scale inversion, referred to as CO_EMS. The value is calculated as (CO_EMS - CO_KF) / CO_KF.

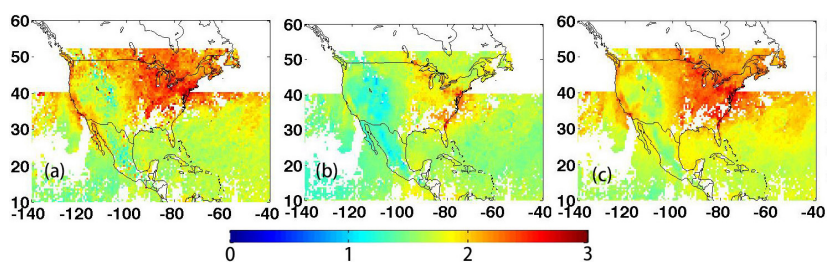

Figure 4. Mean tropospheric CO columns $\left(10^{18}\right.$ molec $\left.\mathrm{cm}^{-2}\right)$ in the GEOS-Chem North American nested domain in June 2004 from (a) MOPITT version 5; (b) GEOS-Chem model with the original initial and boundary conditions; (c) with the optimized initial and boundary conditions. Note that MOPITT data poleward of 40 and $52^{\circ}$ over oceans and land, respectively, are not used in this work to reduce the influence of potential positive bias in MOPITT CO retrievals, as described in Jiang et al. (2015).

significant feature is the positive residual bias along the Intertropical Convergence Zone (ITCZ), suggesting errors in convective transport in the model (e.g., Jiang et al., 2013; Worden et al., 2013).

Since the objective of this work is to constrain the North American CO emissions, using CO_EMS for the boundary conditions may lead to biases in Mexico, the southern US, and along the North American west coast. Consequently, we decided to use the a posteriori fields from the Kalman filter as our optimized boundary conditions. The impact of the initial and boundary conditions from the Kalman filter assimilation is shown in Fig. 4. Driven with original initial and boundary conditions (without assimilation), the modeled $\mathrm{CO}$ columns (Fig. 4b) are obviously lower than that of the MOPITT observations over the North American continent. The difference over the continent is much smaller when the initial and boundary conditions are optimized (Fig. 4c) with the

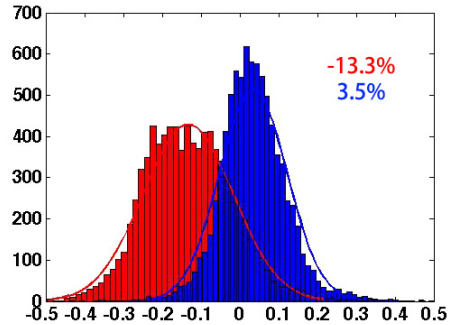

Figure 5. Distribution of the relative bias between the model and MOPITT with the original initial and lateral boundary conditions (red) and the the optimized initial and lateral boundary conditions (blue), after assimilation of the MOPITT data using the Kalman filter. The numbers are the mean relative difference.

assimilation of the MOPITT profiles. It is clear that a significant bias will be introduced in the a posteriori regional emission estimates if the original initial and boundary conditions were used in the inversion analyses. As described in Jiang et al. (2015), we do not assimilate MOPITT data at high latitudes due to a potential positive bias in the $\mathrm{CO}$ retrievals at high latitudes; we only assimilate MOPITT data equatorward of $40^{\circ}$ over oceans and $52^{\circ}$ over land, as shown in Fig. 4.

The distribution of the relative differences between the modeled and observed CO fields is shown in Fig. 5. With both the free running model and the optimized initial and boundary conditions, the distribution of the differences with respect to the MOPITT data are approximately Gaussian. The free running model has a low bias of $-13.3 \%$. Assimilating the MOPITT profile data to optimize the initial and boundary conditions reduced the mean bias to $3.5 \%$, which should produce a better constraint on local North American emissions. 


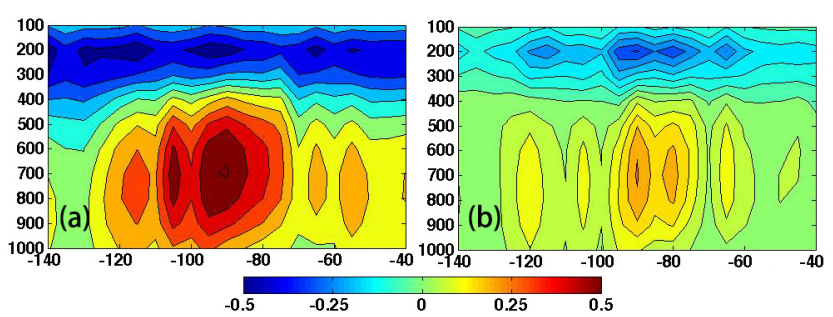

Figure 6. Vertical distribution of relative difference in June 2004 along the southern boundary, between model and MOPITT, calculated as (Mod-MOP) / MOP. (a) original model simulation. (b) optimized model simulation by assimilating MOPITT data using the Kalman filter.

Although the mean a posteriori bias in the initial and boundary conditions is small, the largest residual bias in the boundary conditions is found on the southern boundary (near $10^{\circ} \mathrm{N}$ ), where the a posteriori bias can be as large as $20 \%$ (between 80 and $100^{\circ} \mathrm{W}$ ). The vertical distribution of the relative bias along the southern boundary is shown in Fig. 6. In lower troposphere, the original model simulation has a large positive bias (Fig. 6a), approaching $50 \%$, which the Kalman filter assimilation significantly reduces (Fig. 6b). The inability of the assimilation to more strongly reduce the bias is likely due to limited MOPITT observational coverage over South America, associated with cloud cover (Keller et al., 2015).

A similar bias over the eastern Pacific $\left(0-12^{\circ} \mathrm{N}, 77.5-\right.$ $122.5^{\circ} \mathrm{W}$ ) was reported by Liu et al. (2010) in their comparison of CO data from the Tropospheric Emission Spectrometer (TES) and GEOS-Chem driven by GEOS-4 and GEOS-5 meteorological fields, for 2005 and 2006 (see their Figs. 3 and 4). Relative to TES, the GEOS-Chem was biased high at $681 \mathrm{hPa}$ over the region, which Liu et al. (2010) attributed to excessive export of South American biomass burning emissions, which typically peak in August-September. The magnitude of the bias was larger with GEOS-4 fields than with GEOS-5 (which are used here), and varied from year to year, reflecting the variability in the biomass burning emissions; the model bias was larger in 2005 than in 2006. In Fig. 6 we see that relative to MOPITT, the model is biased low in the upper troposphere. This reflects, in part, the high bias in the MOPITT V5J retrievals in the upper troposphere. However, Liu et al. (2010) found that relative to CO data from the Microwave Limb Sounder (MLS), the model (driven by GEOS5) was also biased low over the eastern Pacific at $215 \mathrm{hPa}$ in August-September 2006, whereas it was biased high in 2005 (see their Figs. 5 and 6). The residual bias on the southern boundary will clearly impact the source estimates obtained here, with the high bias in the lower troposphere resulting in an over adjustment (i.e., underestimation) of the $\mathrm{CO}$ emission estimates in June-October in southern North America (Mexico and the southern US). Since the TES retrievals are carried out in the presence of clouds, the TES data may provide additional information on $\mathrm{CO}$ in the outflow region. Thus, assimilating TES and MOPITT with the Kalman filter may help further reduce the bias the southern boundary conditions. Another promising approach is the weak-constrained 4D-Var technique, recently implemented in GEOS-Chem by Keller et al. (2015), in which the cost function Eq. (2) is augmented with an addition term to mitigate the model transport errors.

\subsection{CO source estimates for June 2004-May 2005}

Figure 7 shows the monthly scaling factors, which are the ratio of the a posteriori to a priori emissions, for June 2004 May 2005. The figure shows enhancement of anthropogenic $\mathrm{CO}$ emissions in the Great Lakes region and along the US west coast. The annual total anthropogenic emission for the contiguous US 48 states is increased by $14 \%$, from 85 to $97 \mathrm{Tg}$. This estimate is consistent with the results of our global inversion analysis presented in Jiang et al. (2015). The annual total North American $\mathrm{CO}$ emission from the oxidation of biogenic VOCs is reduced by $17 \%$, from 61 to $51 \mathrm{Tg}$ with the largest reduction around the Gulf of Mexico in July-September 2004. A possible reason for this reduction is the overestimation of isoprene emission in the MEGANv2.0 inventory used in this work. As discussed in Jiang et al. (2015) several previous studies have suggested that the MEGANv2.0 isoprene emissions are biased high over North America. Hu et al. (2015) found that using the MEGANv2.1, together with an improved land cover distribution, in GEOS-Chem successfully reproduced isoprene observations in North America. However, the MEGANv2.1 inventory is not yet available in the GEOS-Chem adjoint model. It is also possible that the reduction in the biogenic emissions, which are strongest in the southern US, is due, in part, to the high bias in the southern boundary conditions.

The time series for the a priori and a posteriori estimates for different emission categories are shown in Fig. 8 for all of North America $\left(15-65^{\circ} \mathrm{N}\right)$ and for the contiguous US 48 states. For the whole continent, generally, the "bottom-up" inventory shows high $\mathrm{CO}$ emissions in summer and lower values in winter. This seasonal variation is driven by the oxidation of biogenic VOCs, which is significant in MaySeptember and peaks in July, and by biomass burning, which is at a maximum in April in Mexico and in August in boreal Canada. The uncertainty of the anthropogenic emissions is assumed to be small. The analysis, however, does suggest greater anthropogenic emissions in January-May 2005, which accounts for the larger total $\mathrm{CO}$ emissions for this period, as shown in Fig. 8.

The United States is the largest CO source in North America, contributing $63 \%$ to the total North American source. The monthly a priori source in July is $16 \mathrm{Tg}$, twice as large as the source in winter. The distinct seasonal variation is driven by the strong biogenic VOCs source in summer. During January-April 2005, the total a posteriori CO source in 


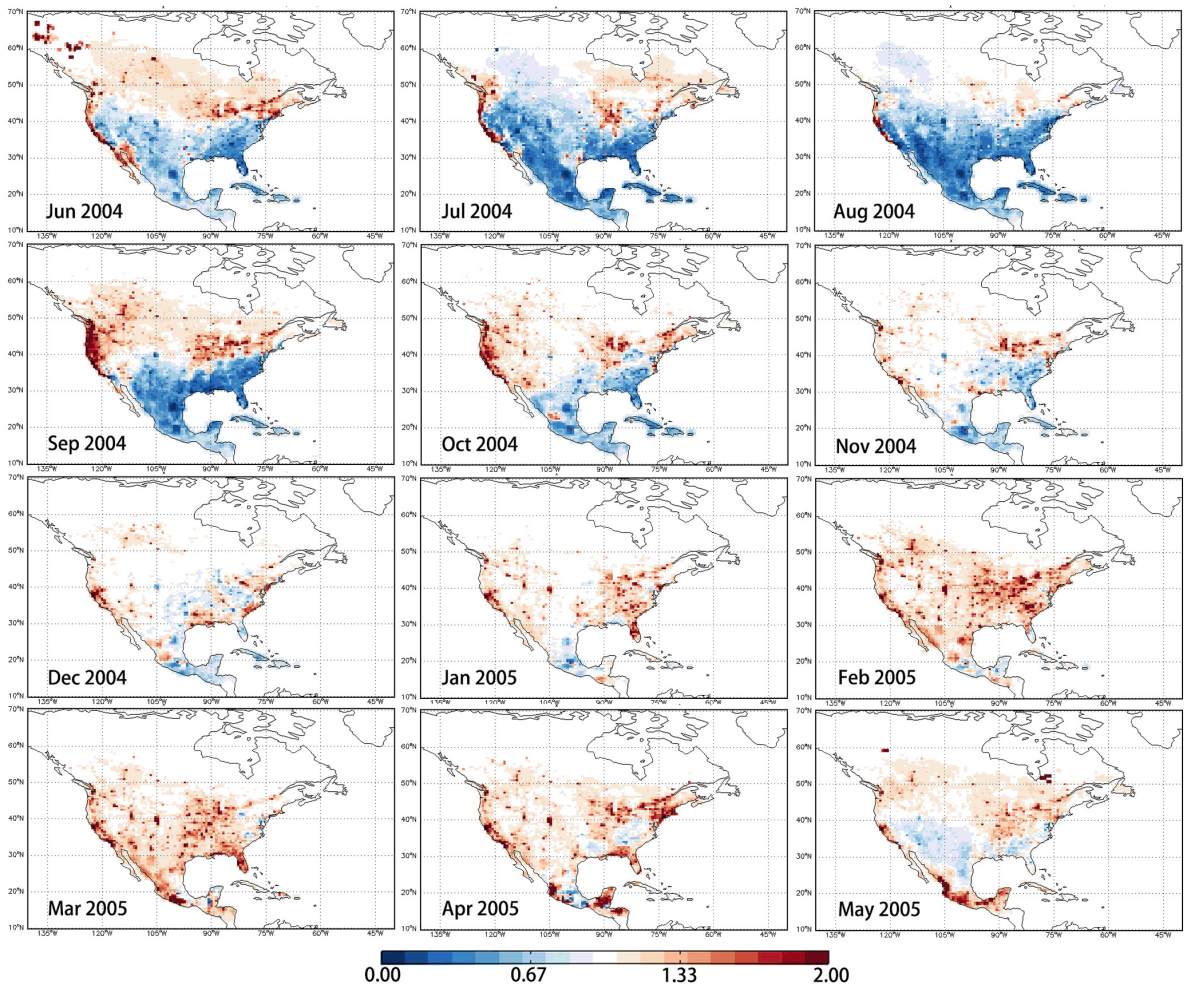

Figure 7. Monthly scaling factor for total CO emissions (from combustion sources and the oxidation of biogenic NMVOC) during June 2004May 2005.

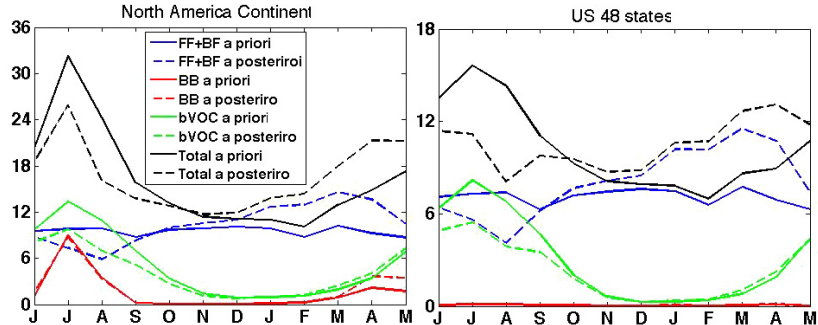

Figure 8. Monthly CO emissions during June 2004-May 2005 for different emission categories: total emissions (black), anthropogenic emissions (blue), biomass burning (red), and the oxidation of biogenic NMVOCs (green). The a priori estimates are shown with the solid line and a posteriori values are indicated with the dashed line. The unit is $\mathrm{Tg}$ month $^{-1}$.

this region is $59 \mathrm{Tg}, 36 \%$ higher than the a priori value. On the contrary, during June-August 2004, the total a posteriori $\mathrm{CO}$ source in this region is $31 \mathrm{Tg}, 29 \%$ lower than the a priori value. This significant discrepancy between summer and winter was also observed by Kopacz et al. (2010). The estimated winter emissions of Kopacz et al. (2010) are about $50 \%$ larger than the summer emissions. Kopacz et al. (2010) and Stein et al. (2014) attributed the higher wintertime emissions in the Northern Hemisphere to vehicular emissions, which are not account for in the a priori emission inventory.
The monthly total CO emissions for the contiguous US 48 states agrees well with the results from the global $4^{\circ} \times 5^{\circ}$ resolution inversion of Jiang et al. (2015). The largest difference is observed in December 2004, when the a posteriori emission estimate from the coarse-resolution inversion is $17 \%$ higher. The smallest difference is observed in October 2004, when the a posteriori emission estimate of the coarse-resolution inversion is $2 \%$ higher. As discussed in Jiang et al. (2015), the seasonal variations of the a posteriori source estimates obtained here are consistent with those of Kopcz et al. (2010), but the magnitude of the source estimates differ significantly, reflecting differences in the configuration of the inversions analyses. We refer the reader to Jiang et al. (2015) for a more detailed discussion of the differences between the source estimates obtained here and those from Kopacz et al. (2010).

Although there is good agreement at continental scales between our high-resolution inverse analysis and the courseresolution inversion of Jiang et al. (2015), we do observe significant differences at regional scales. In June 2004, the highresolution inversion shows large changes, along the west coast, whereas the spatial variation is much smaller in the coarse-resolution inversion, due to averaging on the model grid. More pronounced discrepancies are observed in December 2004. The coarse-resolution inversion shows the a priori $\mathrm{CO}$ emission estimates over the eastern US should be 


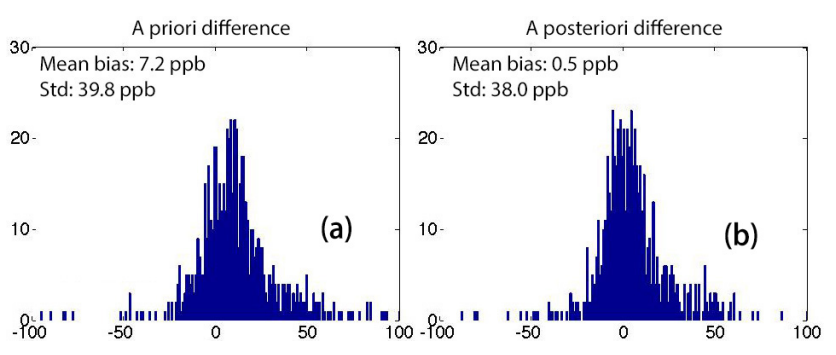

Figure 9. Difference between the GEOS-Chem simulation with INTEX-A DC-8 aircraft observation in free troposphere in July 2004. (a) A priori model simulation (based on the optimized initial and boundary conditions). (b) A posteriori model simulation. The model is sampled at the aircraft measurements time, location and altitude.

increased by $20-50 \%$. However, the high-resolution inversion shows much more variation on regional or urban scales. For example, there is a significant $\mathrm{CO}$ emission decrease in the Toronto area, whereas there are large increases to the east of Lake Ontario. There is also significant $\mathrm{CO}$ emission reduction in West Virginia, and large increases in North and South Carolina. The greater spatial structure in the regional emission estimates is somewhat expected because of the higher spatial resolution, but it is unclear as to how reliable these features are, given the information content of the MOPITT data.

The Intercontinental Transport Experiment - North America, Phase A (INTEX-A) campaign was conducted during 1 July-15 August 2004, over North America (Singh et al., 2006). A DC-8 aircraft was used to measure gas and aerosol abundances, including $\mathrm{CO}, \mathrm{NO}_{2}$, formaldehyde ( $\mathrm{HCHO}$ ), and $\mathrm{H}_{2} \mathrm{O}$, over an altitude range from 0.2 to $12.5 \mathrm{~km}$. In this work, the aircraft measurements from the INTEX-A DC-8 aircraft in July 2004 are used to evaluate the inversion results obtained from MOPITT data. Figure 9 shows the difference between the GEOS-Chem simulation and the INTEX-A DC8 aircraft observation in free troposphere. The inverse model significantly reduces the positive bias in the model bias relative to the aircraft measurements, from 7.2 to $0.5 \mathrm{ppb}$, suggesting that the a posteriori $\mathrm{CO}$ does indeed provide a better regional fit to the independent aircraft data. The reduction in the bias relative to the aircraft data also suggests that vertical transport within North America is unbiased, since such a transport bias in the inversion would degrade the agreement with aircraft data that were obtained with the optimized initial and boundary conditions (the a priori).

\subsection{Sensitivity of regional source estimates to $\mathrm{OH}$}

Following Jiang et al. (2015) we assess the sensitivity of the source estimates to the $\mathrm{OH}$ fields by repeating the inversion for June-August 2004 with the OH fields from version v802-01 of GEOS-Chem. We focus on just the summer months for comparison with Jiang et al. (2015). Also, the $\mathrm{OH}$ impact is expected to be greater in summer, when the $\mathrm{CO}$ lifetime is short. The initial and boundary conditions for this inversion were obtained by assimilating the MOPITT V5J profiles into the model with the Kalman filter and the v8-02-01 OH fields from 1 January 2004 to 1 September 2004. The inversion based on these initial and boundary conditions is referred to as v8OH_BCv8. Our standard inversion with initial and boundary conditions based on the v5-07-08 $\mathrm{OH}$ is referred to as v5OH_BCv5. As discussed in Jiang et al. (2015), the $\mathrm{OH}$ concentrations in $\mathrm{v} 8-02-01$ are significantly higher than the v5-07-08 version in the Northern Hemisphere, and consequently, the $\mathrm{CO}$ lifetime is about $30 \%$ shorter.

Figures $10 \mathrm{a}-\mathrm{c}$ show the scaling factors for the $\mathrm{v} 8 \mathrm{OH} \_\mathrm{BCv} 8$ inversion. The differences relative to the standard inversion (v5OH_BCv5) are shown in Fig. 10d-f. The relative difference in the a posteriori $\mathrm{CO}$ emission estimates in the contiguous US 48 states inferred from the two $\mathrm{OH}$ fields is $32 \%$, suggesting that the $\mathrm{OH}$ fields still have a significant impact on the a posteriori estimates, even with the optimized boundary conditions. The relative difference of $32 \%$ is $20 \%$ smaller than the relative difference $(40 \%)$ obtained by Jiang et al. (2015) in their $4^{\circ} \times 5^{\circ}$ resolution global-scale inversion. Although the $\mathrm{OH}$-related error is smaller than in the global, coarse-resolution inversion, it is still surprisingly large. Figure $10 \mathrm{j}-1$ show the relative differences between the boundary conditions obtained from the v5-07-08 and the v8-02-01 OH fields, which were used in the $\mathrm{v} 5 \mathrm{OH} \_\mathrm{BCv} 5$ and $\mathrm{v} 8 \mathrm{OH} \_\mathrm{BCv} 8$ inversions, respectively. Under ideal conditions, the difference between two boundary conditions should be small because both were optimized with the same MOPITT data using the same approach. However, we do see large differences of more than $15 \%$ along the northern and northeastern boundaries, suggesting our optimization of the boundary conditions is inadequate. We believe that the main reason for this is that we neglected MOPITT data at high latitudes (see Fig. 4) to avoid a potential positive bias in the data. Assimilating data from multi-instruments, such as was done by Kopacz et al. (2010), could provide better data coverage at high latitudes, and thus a better constraint on the northern boundary conditions. Moving the northern boundary to lower latitude would be also helpful.

To quantify the contribution of the differences in the boundary conditions to the differences in the source estimates, we repeated the inversion using the v8-02-01 $\mathrm{OH}$ fields, but with the initial and boundary conditions obtained with v5-07-08 $\mathrm{OH}$. This inversion is referred to as $\mathrm{v} 8 \mathrm{OH}$ BCv5. Since the initial and boundary conditions in the $\mathrm{v} 8 \mathrm{OH} \_\mathrm{BCv} 5$ and v5OH_BCv5 inversions are identical, the differences in the source estimates obtained from these will reflect only the influence of the $\mathrm{OH}$ differences over North America. Figure $10 \mathrm{~g}-\mathrm{i}$ show the differences between $\mathrm{v} 8 \mathrm{OH} \_\mathrm{BCv} 5$ and v5OH_BCv5 (our standard inversion). The relative difference in the a posteriori $\mathrm{CO}$ emission estimates for the contiguous US 48 states is only $20 \%$, which is $50 \%$ 


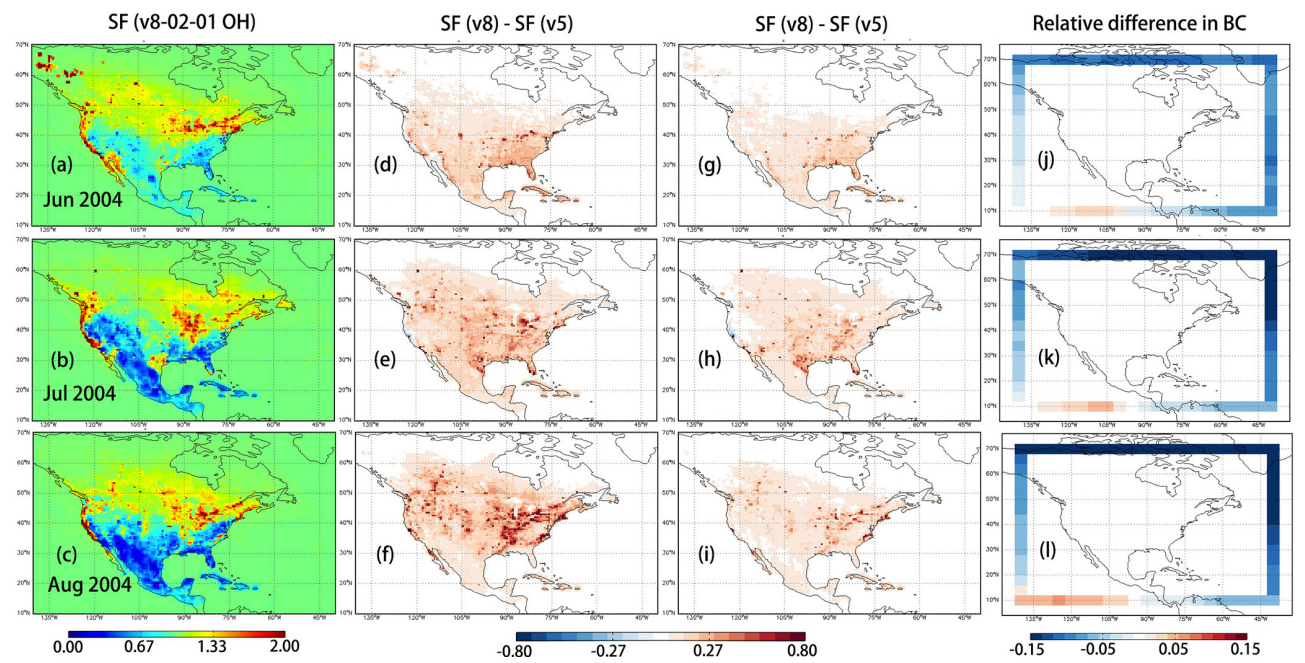

Figure 10. (a-c) Scaling factors of $\mathrm{v} 8 \mathrm{OH} \_\mathrm{BCv} 8$ inversion, based on the v8-02-01 OH; $(\mathbf{d}-\mathbf{f})$ difference between scaling factors of the v5OH_BCv5 and v8OH_BCv8 inversions; $(\mathbf{g}-\mathbf{i})$ similar to $(\mathbf{d}-\mathbf{f})$, but for the v8OH_BCv5 inversion, with the initial and boundary conditions from the standard inversion with the v5-07-08 $\mathrm{OH}$ fields; (j-l) relative difference between the lower tropospheric CO partial columns (surface-500 hPa) of the boundary conditions for the v5OH_BCv5 (v5) and the v8OH_BCv8 (v8) inversions, calculated as $2 \cdot(\mathrm{v} 8-\mathrm{v} 5) /(\mathrm{v} 8+\mathrm{v} 5)$.

smaller than the relative difference obtained by Jiang et al. (2015) in their $4^{\circ} \times 5^{\circ}$ global inversion. The large reduction in the impact of $\mathrm{OH}$ on the source estimates compared to the global-scale inversion is encouraging, and demonstrates the potential advantages of high-resolution regional inversion analyses.

\section{Summary}

High-resolution CTM simulations have obvious accuracy advantages over coarse resolution simulations, particularly for small-scale processes (e.g., Stroud et al., 2011; Klich and Fuelberg, 2014; Stock et al., 2014). In this work, we used the adjoint of the nested GEOS-Chem model, at a resolution of $0.5^{\circ} \times 0.67^{\circ}$, to constrain North American CO emissions during the period of June 2004-May 2005. To reduce the potential impact of discrepancies in the modeled $\mathrm{OH}$ field on the source estimates, we used the V5J surface-level MOPITT retrievals. Our results show that the annual total anthropogenic $\mathrm{CO}$ emissions for the contiguous US 48 states should be increased by $14 \%$, from 85 to $97 \mathrm{Tg}$ for 2004 2005. The adjustment was mainly caused by an increase in emissions near the Great Lakes and along the west coast. The inversion analysis also suggested that the total $\mathrm{CO}$ emissions should be increased by $36 \%$ during January-April 2005, and decreased by $29 \%$ during June-August 2004. This seasonal variation was also observed by Kopacz et al. (2010), and could be associated with an underestimation of road traffic emission in winter (Stein et al., 2014). The inversion results were evaluated with in situ measurements from the DC- 8 aircraft during the INTEX-A campaign in July 2004. The mean bias between the model and the aircraft data in the free troposphere was reduced from $7.2 \mathrm{ppb}$ with the a priori emissions to $0.5 \mathrm{ppb}$ with the a posteriori emissions.

Reliable initial and boundary conditions are critical for regional inversion analyses. We used a sequential sub-optimal Kalman filter (Parrington et al., 2008) to assimilate MOPITT $\mathrm{CO}$ profiles to optimize the distribution of $\mathrm{CO}$ (rather than the emissions) to produce improved initial and lateral boundary conditions for the regional inversion analyses. Because of the restricted domain of the regional analyses, the optimized boundary conditions should significantly reduce the sensitivity of the estimated $\mathrm{CO}$ sources to errors in long-range transport and in the $\mathrm{OH}$ distribution. We found that the Kalman filter assimilation significantly improved the initial and lateral boundary conditions, reducing the bias from -13.3 to $3.5 \%$. However, there was a large residual bias in the southern boundary (near $10^{\circ} \mathrm{N}$, between 80 and $100^{\circ} \mathrm{W}$ ), in the outflow region for biomass burning emissions from South America, which could result in an over adjustment of the $\mathrm{CO}$ emissions in Mexico and the southern US. Comparison of the inversion results driven with two different $\mathrm{OH}$ fields, from version v5-07-08 and v8-02-01 of GEOS-Chem, produced relative differences in the North American source estimates of $32 \%$ for June-August 2004. This OH-related difference in the source estimates is about $20 \%$ smaller than the differences obtained by Jiang et al. (2015) for the same period in their global-scale inversion analysis.

Examination of the differences in the boundary conditions based on the two $\mathrm{OH}$ fields showed large relative differences (greater than 15\%) in the northern and northeastern boundaries, suggesting that our optimization of the boundary conditions was inadequate. In our assimilation of the MOPITT 
data we neglected data poleward of $52^{\circ}$ and $40^{\circ}$ over land and oceans, respectively, to avoid the influence of a potential high-latitude bias in the data, and we believe that this accounted for the weaker constraint on the northern boundary conditions in the analysis. To assess the influence of the boundary conditions we repeated the inversion with the v802-01 OH fields using the same initial and boundary conditions from the standard inversion using the v5-07-08 $\mathrm{OH}$. In this case, we estimated a relative difference between the source estimates based on the v8-02-01 and v5-07-08 OH fields of $20 \%$, which is $50 \%$ smaller than that reported by Jiang et al. (2015). Thus, our best estimate for North American CO emissions for 2004-2005 is $97 \mathrm{Tg}$, with a potential error of $20 \%$, associated with discrepancies in local North American $\mathrm{OH}$.

Our results demonstrate that high-resolution, regional inversion analyses can reduce the sensitivity of the inferred $\mathrm{CO}$ source estimates to errors in long-range transport and in the OH distributions. However, the $20 \%$ OH-related discrepancy that we estimated is still large, and could indicate that more stringent constraints on the regional boundary conditions are needed. This may be achieved by integrating data from multiple sources. The $\mathrm{OH}-$ related discrepancies could also reflect that fact that in summer, air in the middle and upper troposphere over North America is trapped by a semipermanent anticyclone, which allows greater chemical aging than direct lateral export from the continent ( $\mathrm{Li}$ et al., 2005; Cooper et al., 2007). Although the MOPITT surface-level retrievals have peak sensitivity to $\mathrm{CO}$ near the boundary layer, their sensitivity extend up to the middle troposphere (see Fig. 1a of Jiang et al., 2013). Consequently, the inversion analyses could be sensitive to chemical aging of air in the North American anticyclone. Work is needed to determine the residence time for air in the anticyclone compared to the spatiotemporal variability of the constraints on the North American source estimates provided by the MOPITT surface-level retrievals. Improving the source estimates will likely require assimilating sufficient information to obtain a strong constraint on the $\mathrm{CO}$ distribution on a timescales shorter than the timescale for chemical aging in the domain. Despite these limitations, we believe that our results show the potential advantages of combining high-resolution regional inversion analyses with global analyses to better quantify regional $\mathrm{CO}$ source estimates. 


\section{Appendix A: Observing system simulation} experiments (OSSE)

The reliability of the nested inversion is examined with an OSSE for the period 1-15 June 2004. In the OSSE, we firstly create pseudo-observations, by archiving model output with $\mathrm{CO}$ emission unchanged. In the pseudo-inversion, we reduced the $\mathrm{CO}$ emission by $50 \%$ and the objective of the OSSE is to observe whether the scaling factors can return to true state (1.0). Figure A1a shows the result of the reference global scale inversion with $4^{\circ} \times 5^{\circ}$ resolution. The a posteriori estimation converges to the true state in all major emission regions. In the nested inversion (Fig. A1c), the model converges to the true state in the eastern US, whereas the result is noisy in the western US and Canada, which is consistent with the global scale inversion, as shown in Fig. A1b. The OSSE demonstrates the nested inversion has similar reliability as the global scale assimilation system.
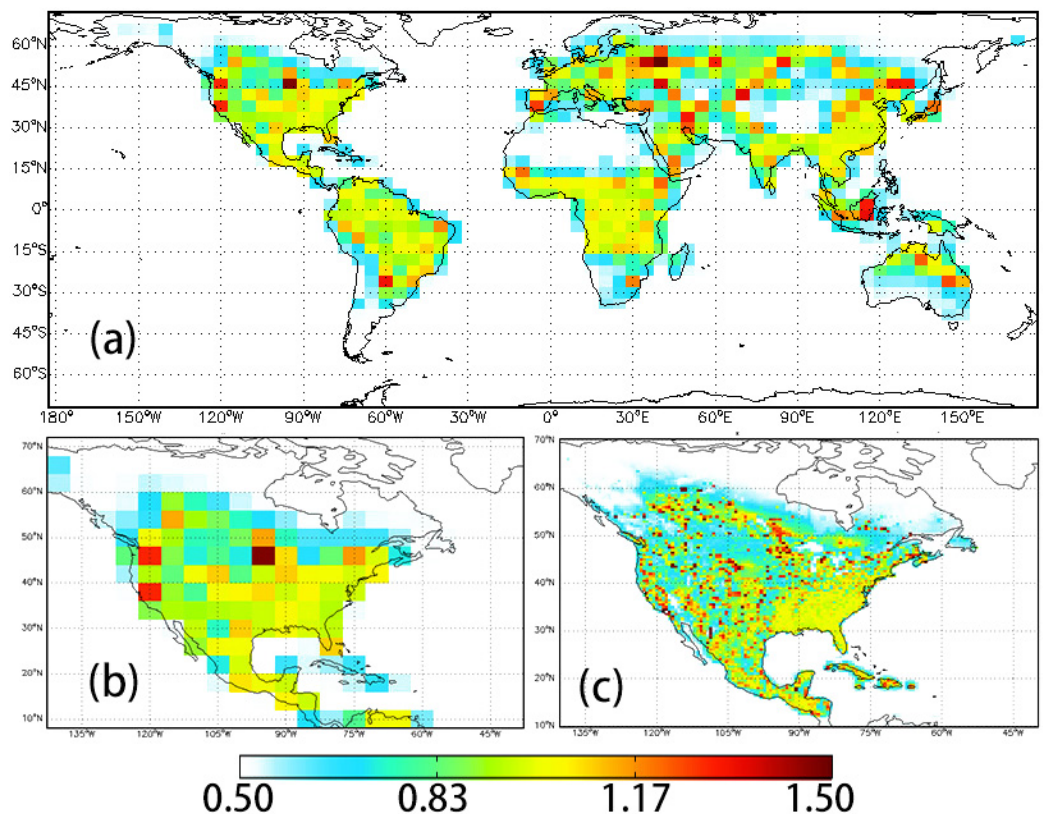

Figure A1. OSSE scaling factors for 1-15 June 2004. (a) Global reference inversion with $4^{\circ} \times 5^{\circ}$ resolution. (b) Zoomed in the North American region of the global inversion. (c) Nested inversion results. The scaling factor for the first guess is 0.5 and for the true state is 1.0 . 
Acknowledgements. This work was supported by funding from the Natural Science and Engineering Research Council of Canada, the Canadian Space Agency, and NASA grants NNX10AT42G and NNX11AI54G.

Edited by: B. N. Duncan

\section{References}

Arellano Jr., A. F., Kasibhatla, P. S., Giglio, L., van der Werf, G. R., Randerson, J. T., and Collatz, G. J.: Time dependent inversion estimates of global biomass-burning CO emissions using Measurement of Pollution in the Troposphere (MOPITT) measurements, J. Geophys. Res., 111, D09303, doi:10.1029/2005JD006613, 2006.

Bergamaschi, P., Krol, M., Meirink, J., Dentener, F., Segers, A., Aardenne, J., Monni, S., Vermeulen, A., Schmidt, M., Ramonet, M., Yver, C., Meinhardt, F., Nisbet, E., Fisher, R., O'Doherty, S., and Dlugokencky, E.: Inverse modeling of European $\mathrm{CH}_{4}$ emissions 2001-2006, J. Geophys. Res., 115, D22309, doi:10.1029/2010JD014180, 2010.

Brioude, J., Petron, G., Frost, G. J., Ahmadov, R., Angevine, W. M., Hsie, E.-Y., Kim, S.-W., Lee, S.-H., McKeen, S. A., Trainer, M., Fehsenfeld, F. C., Holloway, J. S., Peischl, J., Ryerson, T. B., and Gurney, K. R.: A new inversion method to calculate emission inventories without a prior at mesoscale: Application to the anthropogenic $\mathrm{CO}_{2}$ emission from Houston, Texas, J. Geophys. Res., 117, D05312, doi:10.1029/2011JD016918, 2012.

Chen, D., Wang, Y., McElroy, M. B., He, K., Yantosca, R. M., and Le Sager, P.: Regional CO pollution and export in China simulated by the high-resolution nested-grid GEOS-Chem model, Atmos. Chem. Phys., 9, 3825-3839, doi:10.5194/acp-9-3825-2009, 2009.

Cooper, O., Trainer, M., Thompson, A., Oltmans, S., Tarasick, D., Witte, J., Stohl, A., Eckhardt, S., Lelieveld, J., Newchurch, M., Johnson, B., Portmann, R., Kalnajs, L., Dubey, M., Leblanc, T., McDermid, I., Forbes, G., Wolfe, D., Carey-Smith, T., Morris, G., Lefer, B., Rappenglück, B., Joseph, E., Schmidlin, F., Meagher, J., Fehsenfeld, F., Keating, T., Curen, R., and Minschwaner, K.: Evidence for a recurring eastern North America upper tropospheric ozone maximum during summer, J. Geophys. Res., 112, D23304, doi:10.1029/2007JD008710, 2007.

Corazza, M., Bergamaschi, P., Vermeulen, A. T., Aalto, T., Haszpra, L., Meinhardt, F., O’Doherty, S., Thompson, R., Moncrieff, J., Popa, E., Steinbacher, M., Jordan, A., Dlugokencky, E., Brühl, C., Krol, M., and Dentener, F.: Inverse modelling of European $\mathrm{N}_{2} \mathrm{O}$ emissions: assimilating observations from different networks, Atmos. Chem. Phys., 11, 2381-2398, doi:10.5194/acp11-2381-2011, 2011.

Curci, G., Palmer, P. I., Kurosu, T. P., Chance, K., and Visconti, G.: Estimating European volatile organic compound emissions using satellite observations of formaldehyde from the Ozone Monitoring Instrument, Atmos. Chem. Phys., 10, 11501-11517, doi:10.5194/acp-10-11501-2010, 2010.

Deeter, M. N., Worden, H. M., Gille, J. C., Edwards, D. P., Mao, D., and Drummond, J. R.: MOPITT multispectral CO retrievals: Origins and effects of geophysical radiance errors, J. Geophys. Res., 116, D15303, doi:10.1029/2011JD015703, 2011.
Deeter, M. N., Worden, H. M., Edwards, D. P., Gille, J. C., and Andrews, A. E.: Evaluation of MOPITT retrievals of lowertropospheric carbon monoxide over the United States, J. Geophys. Res., 117, D13306, doi:10.1029/2012JD017553, 2012.

Deeter, M. N., Martínez-Alonso, S., Edwards, D. P., Emmons, L. K., Gille, J. C., Worden, H. M., Pittman, J. V., Daube, B. C., and Wofsy, S. C.: Validation of MOPITT Version 5 thermalinfrared, near-infrared, and multispectral carbon monoxide profile retrievals for 2000-2011, J. Geophys. Res.-Atmos., 118, 6710-6725, doi:10.1002/jgrd.50272, 2013.

Deng, F., Jones, D. B. A., Henze, D. K., Bousserez, N., Bowman, K. W., Fisher, J. B., Nassar, R., O’Dell, C., Wunch, D., Wennberg, P. O., Kort, E. A., Wofsy, S. C., Blumenstock, T., Deutscher, N. M., Griffith, D. W. T., Hase, F., Heikkinen, P., Sherlock, V., Strong, K., Sussmann, R., and Warneke, T.: Inferring regional sources and sinks of atmospheric $\mathrm{CO}_{2}$ from GOSAT $X \mathrm{CO}_{2}$ data, Atmos. Chem. Phys., 14, 3703-3727, doi:10.5194/acp-14-37032014, 2014.

Evans, M. J. and Jacob, D. J.: Impact of new laboratory studies of $\mathrm{N}_{2} \mathrm{O}_{5}$ hydrolysis on global model budgets of tropospheric nitrogen oxides, ozone, and OH, Geophys. Res. Lett., 32, L09813, doi:10.1029/2005GL022469, 2005.

Fortems-Cheiney, A., Chevallier, F., Pison, I., Bousquet, P., Szopa, S., Deeter, M. N., and Clerbaux, C.: Ten years of $\mathrm{CO}$ emissions as seen from Measurements of Pollution in the Troposphere (MOPITT), J. Geophys. Res., 116, D05304, doi:10.1029/2010JD014416, 2011.

Fortems-Cheiney, A., Chevallier, F., Pison, I., Bousquet, P., Saunois, M., Szopa, S., Cressot, C., Kurosu, T. P., Chance, K., and Fried, A.: The formaldehyde budget as seen by a global-scale multiconstraint and multi-species inversion system, Atmos. Chem. Phys., 12, 6699-6721, doi:10.5194/acp-12-6699-2012, 2012.

Göckede, M., Turner, D. P., Michalak, A. M., Vickers, D., and Law, B. E.: Sensitivity of a subregional scale atmospheric inverse $\mathrm{CO}_{2}$ modeling framework to boundary conditions, J. Geophys. Res., 115, D24112, doi:10.1029/2010JD014443, 2010.

Gonzi, S., Feng, L., and Palmer, P. I.: Seasonal cycle of emissions of CO inferred from MOPITT profiles of CO: Sensitivity to pyroconvection and profile retrieval assumptions, Geophys. Res. Lett., 38, L08813, doi:10.1029/2011GL046789, 2011.

Heald, C. L., Jacob, D. J., Jones, D. B. A., Palmer, P. I., Logan, J. A., Streets, D. G., Sachse, G. W., Gille, J. C., Hoffman, R. N., and Nehrkorn, T.: Comparative inverse analysis of satellite (MOPITT) and aircraft (TRACE-P) observations to estimate Asian sources of carbon monoxide, J. Geophys. Res., 109, D23306, doi:10.1029/2004JD005185, 2004.

Henze, D. K., Hakami, A., and Seinfeld, J. H.: Development of the adjoint of GEOS-Chem, Atmos. Chem. Phys., 7, 2413-2433, doi:10.5194/acp-7-2413-2007, 2007.

Hu, L., Millet, D., Baasandorj, M., Griffis, T., Turner, P., Helmig, D., Curtis, A., and Hueber, J.: Isoprene emissions and impacts over an ecological transition region in the U.S. Upper Midwest inferred from tall tower measurements, J. Geophys. Res.-Atmos., 120, 3553-3571, doi:10.1002/2014JD022732, 2015.

Jiang, Z., Jones, D. B. A., Worden, H. M., Deeter, M. N., Henze, D. K., Worden, J., Bowman, K. W., Brenninkmeijer, C. A. M., and Schuck, T. J.: Impact of model errors in convective transport on CO source estimates inferred from MOPITT CO retrievals, J. Geophys. Res. Atmos., 118, 2073-2083, 2013. 
Jiang, Z., Jones, D. B. A., Worden, H. M., and Henze, D. K.: Sensitivity of top-down $\mathrm{CO}$ source estimates to the modeled vertical structure in atmospheric CO, Atmos. Chem. Phys., 15, 15211537, doi:10.5194/acp-15-1521-2015, 2015.

Jiang, Z., Jones, D., Kopacz, M., Liu, J., Henze, D., and Heald, C.: Quantifying the impact of model errors on top-down estimates of carbon monoxide emissions using satellite observations, J. Geophys. Res., 116, D15306, doi:10.1029/2010JD015282, 2011.

Jones, D. B. A., Bowman, K. W., Logan, J. A., Heald, C. L., Liu, J., Luo, M., Worden, J., and Drummond, J.: The zonal structure of tropical $\mathrm{O}_{3}$ and $\mathrm{CO}$ as observed by the Tropospheric Emission Spectrometer in November 2004 - Part 1: Inverse modeling of $\mathrm{CO}$ emissions, Atmos. Chem. Phys., 9, 3547-3562, doi:10.5194/acp-9-3547-2009, 2009.

Keller, M., Jones, D. B. A., Jiang, Z., Henze, D. K., and Worden, H. M.: Quantifying Model Biases in CO Emission Estimation Using Weak Constraint 4D-Var, J. Geophys. Res., submitted, 2015.

Klich, C. A. and Fuelberg, H. E.: The role of horizontal model resolution in assessing the transport of $\mathrm{CO}$ in a middle latitude cyclone using WRF-Chem, Atmos. Chem. Phys., 14, 609-627, doi:10.5194/acp-14-609-2014, 2014.

Kopacz, M., Jacob, D., Henze, D., Heald, C., Streets, D., and Zhang, Q.: Comparison of adjoint and analytical Bayesian inversion methods for constraining Asian sources of carbon monoxide using satellite (MOPITT) measurements of CO columns, J. Geophys. Res., 114, D04305, doi:10.1029/2007JD009264, 2009.

Kopacz, M., Jacob, D. J., Fisher, J. A., Logan, J. A., Zhang, L., Megretskaia, I. A., Yantosca, R. M., Singh, K., Henze, D. K., Burrows, J. P., Buchwitz, M., Khlystova, I., McMillan, W. W., Gille, J. C., Edwards, D. P., Eldering, A., Thouret, V., and Nedelec, P.: Global estimates of $\mathrm{CO}$ sources with high resolution by adjoint inversion of multiple satellite datasets (MOPITT, AIRS, SCIAMACHY, TES), Atmos. Chem. Phys., 10, 855-876, doi:10.5194/acp-10-855-2010, 2010.

Lauvaux, T., Schuh, A. E., Uliasz, M., Richardson, S., Miles, N., Andrews, A. E., Sweeney, C., Diaz, L. I., Martins, D., Shepson, P. B., and Davis, K. J.: Constraining the $\mathrm{CO}_{2}$ budget of the corn belt: exploring uncertainties from the assumptions in a mesoscale inverse system, Atmos. Chem. Phys., 12, 337-354, doi:10.5194/acp-12-337-2012, 2012.

Li, Q., Jiang, J., Wu, D., Read, W., Livesey, N., Waters, J., Zhang, Y., Wang, B., Filipiak, M., Davis, C., Turquety, S., Wu, S., Park, R., Yantosca, R., and Jacob, D.: Convective outflow of South Asian pollution: A global CTM simulation compared with EOS MLS observations, Geophys. Res. Lett., 32, L14826, doi:10.1029/2005GL022762, 2005.

Liu, D. C. and Nocedal, J.: On the Limited Memory Method for Large Scale Optimization, Math. Program., 45, 503-528, 1989.

Liu, J. H., Logan, J. A., Jones, D. B. A., Livesey, N. J., Megretskaia, I., Carouge, C., and Nedelec, P.: Analysis of CO in the tropical troposphere using Aura satellite data and the GEOS-Chem model: insights into transport characteristics of the GEOS meteorological products, Atmos. Chem. Phys., 10, 12207-12232, doi:10.5194/acp-10-12207-2010, 2010.

Locatelli, R., Bousquet, P., Chevallier, F., Fortems-Cheney, A., Szopa, S., Saunois, M., Agusti-Panareda, A., Bergmann, D., Bian, H., Cameron-Smith, P., Chipperfield, M. P., Gloor, E., Houweling, S., Kawa, S. R., Krol, M., Patra, P. K., Prinn, R.
G., Rigby, M., Saito, R., and Wilson, C.: Impact of transport model errors on the global and regional methane emissions estimated by inverse modelling, Atmos. Chem. Phys., 13, 99179937, doi:10.5194/acp-13-9917-2013, 2013.

Meirink, J. F., Bergamaschi, P., and Krol, M. C.: Fourdimensional variational data assimilation for inverse modelling of atmospheric methane emissions: method and comparison with synthesis inversion, Atmos. Chem. Phys., 8, 6341-6353, doi:10.5194/acp-8-6341-2008, 2008.

Palmer, P., Jacob, D., Jones, D., Heald, C., Yantosca, R., Logan, J., Sachse, G., and Streets, D.: Inverting for emissions of carbon monoxide from Asia using aircraft observations over the western Pacific, J. Geophys. Res., 108, 8828, doi:10.1029/2003JD003397, 2003.

Parrington, M., Jones, D. B. A., Bowman, K. W., Horowitz, L. W., Thompson, A. M., Tarasick, D. W., and Witte, J. C.: Estimating the summertime tropospheric ozone distribution over North America through assimilation of observations from the Tropospheric Emission Spectrometer, J. Geophys. Res., 113, D18307, doi:10.1029/2007JD009341, 2008.

Pétron, G., Granier, C., Khattatov, B., Yudin, V., Lamarque, J.-F., Emmons, L., Gille, J., and Edwards, D. P.: Monthly CO surface sources inventory based on the 2000-2001 MOPITT satellite data, Geophys. Res. Lett., 31, L21107, doi:10.1029/2004GL020560, 2004.

Peylin, P., Houweling, S., Krol, M. C., Karstens, U., Rödenbeck, C., Geels, C., Vermeulen, A., Badawy, B., Aulagnier, C., Pregger, T., Delage, F., Pieterse, G., Ciais, P., and Heimann, M.: Importance of fossil fuel emission uncertainties over Europe for $\mathrm{CO}_{2}$ modeling: model intercomparison, Atmos. Chem. Phys., 11, 66076622, doi:10.5194/acp-11-6607-2011, 2011.

Singh, H. B., Brune, W. H., Crawford, J. H., Jacob, D. J., and Russell, P. B.: Overview of the summer 2004 Intercontinental Chemical Transport Experiment - North America (INTEX-A), J. Geophys. Res., 111, D24S01, doi:10.1029/2006JD007905, 2006.

Singh, K., Jardak, M., Sandu, A., Bowman, K., Lee, M., and Jones, D.: Construction of non-diagonal background error covariance matrices for global chemical data assimilation, Geosci. Model Dev., 4, 299-316, doi:10.5194/gmd-4-299-2011, 2011.

Stein, O., Schultz, M. G., Bouarar, I., Clark, H., Huijnen, V., Gaudel, A., George, M., and Clerbaux, C.: On the wintertime low bias of Northern Hemisphere carbon monoxide found in global model simulations, Atmos. Chem. Phys., 14, 9295-9316, doi:10.5194/acp-14-9295-2014, 2014.

Stock, Z. S., Russo, M. R., and Pyle, J. A.: Representing ozone extremes in European megacities: the importance of resolution in a global chemistry climate model, Atmos. Chem. Phys., 14, 3899-3912, doi:10.5194/acp-14-3899-2014, 2014.

Stroud, C. A., Makar, P. A., Moran, M. D., Gong, W., Gong, S., Zhang, J., Hayden, K., Mihele, C., Brook, J. R., Abbatt, J. P. D., and Slowik, J. G.: Impact of model grid spacing on regionaland urban- scale air quality predictions of organic aerosol, Atmos. Chem. Phys., 11, 3107-3118, doi:10.5194/acp-11-31072011, 2011.

Valin, L. C., Russell, A. R., Hudman, R. C., and Cohen, R. C.: Effects of model resolution on the interpretation of satellite $\mathrm{NO}_{2}$ observations, Atmos. Chem. Phys., 11, 11647-11655, doi:10.5194/acp-11-11647-2011, 2011. 
Wang, Y. X., McElroy, M. B., Jacob, D. J., and Yantosca, R. M.: A nested grid formulation for chemical transport over Asia: Applications to CO, J. Geophys. Res., 109, D22307, doi:10.1029/2004JD005237, 2004.

Wecht, K. J., Jacob, D. J., Sulprizio, M. P., Santoni, G. W., Wofsy, S. C., Parker, R., Bösch, H., and Worden, J.: Spatially resolving methane emissions in California: constraints from the CalNex aircraft campaign and from present (GOSAT, TES) and future (TROPOMI, geostationary) satellite observations, Atmos. Chem. Phys., 14, 8173-8184, doi:10.5194/acp-14-8173-2014, 2014.

Wells, K. C., Millet, D. B., Cady-Pereira, K. E., Shephard, M. W., Henze, D. K., Bousserez, N., Apel, E. C., de Gouw, J., Warneke, C., and Singh, H. B.: Quantifying global terrestrial methanol emissions using observations from the TES satellite sensor, Atmos. Chem. Phys., 14, 2555-2570, doi:10.5194/acp-14-25552014, 2014.
Worden, H. M., Deeter, M. N., Edwards, D. P., Gille, J. C., Drummond, J. R., and Nédélec, P.: Observations of near-surface carbon monoxide from space using MOPITT multispectral retrievals, J. Geophys. Res., 115, D18314, doi:10.1029/2010JD014242, 2010.

Worden, J., Jiang, Z., Jones, D., Alvarado, M., Bowman, K., Frankenberg, C., Kort, E., Kulawik, S., Lee, M., Liu, J., Payne, V., Wecht, K., and Worden, H.: El Niño, the 2006 Indonesian peat fires, and the distribution of atmospheric methane,Geophys. Res. Lett., 40, 4938-4943, doi:10.1002/grl.50937, 2013. 